\title{
Genetic Variants of Interleukin-18 Promoter Gene in Coronary Artery Disease
}

\author{
Ibrahim H. Borai ${ }^{1}$, Nahla S. Hassan ${ }^{1}$, Olfat G. Shaker ${ }^{2}$, Esmat Ashour ${ }^{3}$, \\ Mohammed EI Badrawy ${ }^{4}$, Olfat M. Fawzi ${ }^{3}$ and Lamiaa Mageed ${ }^{3 *}$ \\ ${ }^{1}$ Biochemistry Department, Faculty of Science, Ain Shams University, Cairo, \\ ${ }^{2}$ Medical Biochemistry and Molecular Biology Department, Faculty of Medicine, \\ Cairo University, ${ }^{3}$ Biochemistry Department, The National Research Centre and ${ }^{4}$ The \\ National Heart Institute, Giza, Egypt.
}

$\mathbf{H}$ EART disease is impacted by ecological and inherited factors. Interleukin-18 (IL-18) is a pro-inflammatory cytokine that stimulates the immune reaction and induces the formation of atherosclerotic plaques. The aim of this study was to determine the relation between IL-18 promoter variants at $(607 \mathrm{C} / \mathrm{A})$ and $(137 \mathrm{G} / \mathrm{C})$ sites and coronary artery disease $(\mathrm{CAD})$. A sum of one hundred and twenty Egyptian patients (Sixty with CAD and sixty without CAD) and fifty healthy controls were consolidated into the study. Genotyping of IL18 promoter gene was investigated by PCR - Specific Sequence primer (PCR-SSP) technique. The outcomes demonstrated that a significant association between lipid profiles and risk for CAD. At position-137, the recurrence of GG genotype was fundamentally connected with CAD. No qualifications in the genotypic and allelic frequencies amongst cases and controls were found for IL-18 (607C/A) promoter gene. A relationship between IL-18 (137G/C) promoter gene and vulnerability to CAD was proposed and it might serve as susceptibility biomarkers in the pathogenesis of atherosclerosis.

Keywords: Coronary Artery Disease (CAD), Inflammation, Interleukin-18 (IL-18), Gene polymorphism

\section{Introduction}

There were a multifactorial sickness and a noteworthy reason for morbidness and mortality in all races, ethnicities, and social orders in atherosclerotic coronary artery disease (CAD) [1] A few hazard factors, for instance, hypertension, smoking, hyperlipidemia, obesity, and diabetes, have been associated with $\mathrm{CAD}[2,3]$.

There was a key part for the provocative pathway in the improvement and entanglements of CAD [4]. Pro-inflammatory adds to the onset and/or to the movement of atherosclerotic appearances, through destabilizing coronary atherosclerotic plaque, and impelling of intense coronary disorders [5].

Interleukin-18 (IL-18) is a pro-inflammatory cytokine with a critical role in the inflammation that adds to atherosclerosis [6]. Expanded levels of circulating IL-18 have been might be connected with quickening of atherosclerosis and may assume a part in intense coronary disorders through plaque destabilization [7].

Variations in the IL-18 gene were connected with raised IL-18 serum focuses and higher cardiovascular mortality among CAD patients. Distinctive studies showed that IL18 polymorphisms are incorporated into the advancement of ischemic stroke [8], dead tissue [9], and higher cardiovascular mortality risk [6].

Interleukin-18 protein expression is controlled by the IL-18 promoter gene at positions 607 $\mathrm{C} / \mathrm{A}$ and $137 \mathrm{G} / \mathrm{C}$ in the promoter area [10]. These promoter regions are expected to be the binding sites for Cyclic (Adenosine 30, 50-cyclic monophosphate) AMP-responsive elementbinding protein (CREB) and human histone-H4 gene-specific transcription factor-1(H4TF1) [11].

Several studies have examined the association of IL-18 promoter genes and CAD, and the results are inconsistent across different populations $[8$,

Corresponding author e-mail: malakalhoda@yahoo.com,

Post: 12622. Telephone: +201094882552, Fax: 02-33460627

DOI: 10.21608/EJCHEM.2017.1337.1085

C2017 National Information and Documentation Centre (NIDOC) 
27-31]. The aim of the present study was to study the genetic variants of IL-18 (607C/A) and (137 $\mathrm{G} / \mathrm{C}$ ) promoter gene and assess their contributions to coronary artery disease.

\section{Subjects and Methods}

A total of 120 Egyptian patients undergoing cardiac catheterization were enrolled as a part of the Cardiology Section of The National Heart Institute, Giza, Egypt. Subjects were divided into two groups:

Group I): 60 patients (40 males and 20 females; their ages ranged from 32 to 69 years) with documented CAD. Documented CAD was diagnosed by:

a) Electrocardiograph tests, such as an electrocardiogram (ECG or EKG) or exercise stress tests, use the electrocardiogram to evaluate the electrical activity generated by the heart at rest and with activity.

b) Laboratory Tests: include a number of blood tests used to diagnose and monitor treatment for heart disease.

Group П): 60 participants (27 males and 33 females; their ages ranged from 27 to 72 years) were selected among patients without angiographic lesions, were considered as the patients without CAD (Non-CAD).

Beside 50 healthy subjects (37 males and 13 females; their ages ranged from 25 to 55 years) were enrolled as control group, who were age, sex matched with patients and they had no history of CAD, MI or stroke.

There was neither personal nor family history of autoimmune, and metabolic disease or malignancy in both patient and control groups.

All recruited subjects provided blood samples for biochemical and genotype analysis. The study protocol was approved by The Medical Research Ethics Committee of The National Research Centre (NRC) (Registration number-12-042). Written informed consent was obtained from all study participants.

Sampling: Peripheral venous blood samples $(5 \mathrm{ml})$ were drawn under aseptic conditions from all subjects after an overnight fasting of 12-h and divided into two parts; one part $(2 \mathrm{ml})$ of the whole blood was collected in EDTA coated tubes for DNA extraction for detection IL-18 promoter gene polymorphisms. The second part $(3 \mathrm{ml})$ of blood Egypt. J. Chem. 60, No. 5 (2017) allowed to clot for 10-15 minutes then centrifuged at $1000 \mathrm{xg}$ for 5 minutes for serum separation and stored at $-20^{\circ} \mathrm{C}$ in aliquots until required.

Biochemical analysis: Total Cholesterol (TC), Triglyceride (TG) and HDL-C were measured by enzymatic-colorimetric method according to the method described by Allain et al [12], Fossati and Prencipe [13] and Burstein et al [14] respectively using the kit manufactured by STANBIO Laboratory, USA. LDL-C was calculated using formula of Frieldewald et al [15].

DNA analysis: Genomic DNA was isolated from peripheral blood leukocytes using a spin column method according to the protocol (QIAamp Blood Kit; Qiagen GmbH, Hilden, Germany) according to the manufacturer's instructions.

-Genotyping method for (607 C/A) polymorphism of IL-18 promoter gene:

The genotyping of IL-18 (607C/A) was performed by polymerase chain reaction- specific sequence primer (PCR-SSP) method. The sequences of the primers were; a common reverse primer (5'-TAACCTCATTCAGGACTTCC-3') and two sequence specific primers $\left(5^{\prime}\right.$ GTTGCAGAAAGTGTAAAAATTATTAC-3') (for allele $\quad$ C) and(5'GTTGCAGAAAGTGTAAAAATTATTAA-3') (for allele A) were used to amplify a 196-bp product. A control forward primer (5'-CTTTGC TATCATTCCAGGAA-3') was used to amplify a 301-bp fragment covering the polymorphic site according to Giedraitis et al [16]. PCR amplification was performed with 5 pmol of each primer in combination with Taq PCR Master Mix (New England Biolabs Inc., UK). The PCR cycling conditions were : initial denaturation at $94^{\circ} \mathrm{C}$ for $2 \mathrm{~min}$ followed by 30 cycles of denaturation at $94^{\circ} \mathrm{C}$ for $30 \mathrm{~s}$, annealing at $57^{\circ} \mathrm{C}$ for $30 \mathrm{~s}$ and extension at $72^{\circ} \mathrm{C}$ for $30 \mathrm{~s}$ followed by a final extension at $72^{\circ} \mathrm{C}$ for 5 min (T-Gradient Thermal Cycler, Biometra, Germany). The PCR products were analyzed by electrophoresis on 3\% agarose gel stained with Red-Safe then the gel was visualized under UV transilluminator with 100-bp ladder. The PCR products were of 301-bp for (control forward primer) and 196-bp band for (C allele or A allele) (Fig.1).

\section{-Genotyping method for (137 G/C) polymorphism of IL-18 promoter gene}

The genotyping of IL-18 (137 G/C) was performed by polymerase chain reaction- specific 
sequence primer (PCR-SSP) method. The sequences of the primers were; a common reverse primer (5'-AGGAGGGCAAAATGCACTGG-3') and two sequence specific primers (5'CCCCAACTTTTACGGAAGAAAAG-3') (for allele $\mathrm{G}$ ) and (5'CCCCAACTTTTACGGAAGAAAAC-3') (for allele C). An amplification product of 261-bp was detected. A control forward primer (5'CCAATAGGACTGATTATTCCGCA-3') was used to amplify a 446-bp fragment covering the polymorphic site as described by Giedraitis et $a l^{16}$. The PCR cycling conditions were : initial denaturation at $94^{\circ} \mathrm{C}$ for $2 \mathrm{~min}$ followed by 30 cycles of denaturation at $94^{\circ} \mathrm{C}$ for $30 \mathrm{~s}$, annealing at $57^{\circ} \mathrm{C}$ for $30 \mathrm{~s}$ and extension at $72^{\circ} \mathrm{C}$ for $30 \mathrm{~s}$ followed by a final extension at $72^{\circ} \mathrm{C}$ for $5 \mathrm{~min}$. The PCR products were analyzed by electrophoresis on 3\% agarose gel stained with Red-Safe then the gel was visualized under UV transilluminator with 100-bp ladder. The PCR products were of 446-bp for (control forward primer) and 261-bp band for (G allele or $\mathrm{C}$ allele) (Fig.2).

\section{Statistical analysis}

Data are expressed as means \pm standard deviation (SD) for quantitative variables, frequency for qualitative variables. Quantitative variables were compared using independent student t-test and one-
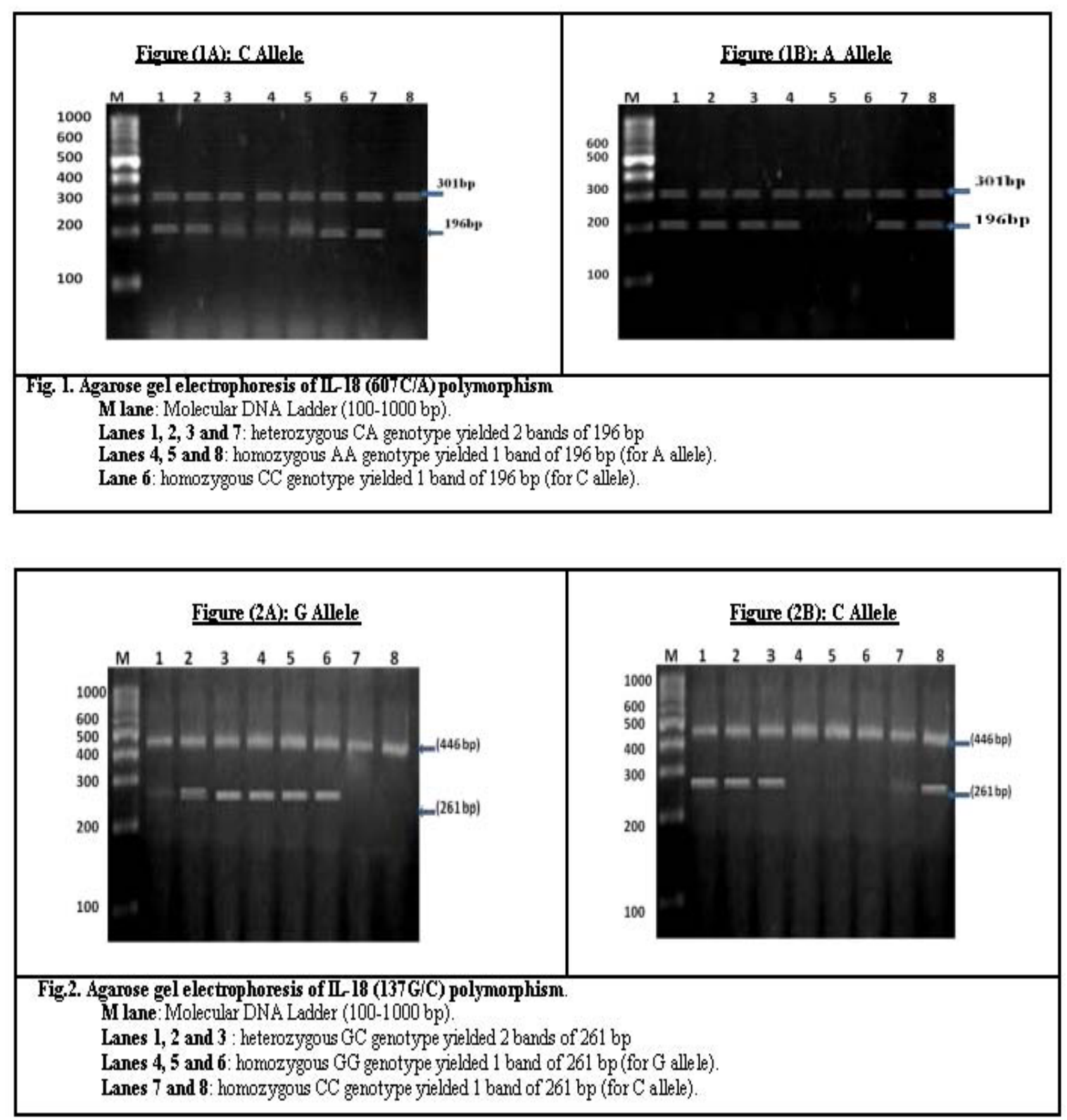

Egypt. J. Chem. 60, No. 5 (2017) 
way ANOVA, LSD test was used for multiple posthoc comparisons. On the other hand, qualitative variables were compared using Chi square $\left(\mathrm{X}^{2}\right)$ test or Fischer's exact test. The statistical Package for the Social Science Software (SPSS 17.0, Chicago, IL, USA) was used, $\mathrm{P}<0.05$ was considered significant.

\section{Results}

Anthropometric characteristics of patients with and without $C A D$ :

The Anthropometric characteristics of patients with and without coronary artery disease (CAD) are shown in (Table 1). There was a significant difference among $\mathrm{CAD}$ and Non-CAD regarding sex distribution. The CAD patients had higher frequencies of $A R$ and RV when compared to the non-CAD group. Furthermore, there were non-significant differences between CAD and non-CAD groups regarding age, diabetes mellitus, obesity, hypertension, smoking, LVEDD, LVESD, LVSWT, LVPWT, LA, EF\% and FS\%.
Biochemical characteristics of all studied groups:

The change of biochemical parameters for patients with and without CAD and control subjects according to lipid profile are shown in (Table 2). The levels of total cholesterol, triglyceride and LDL-C were significantly higher in CAD group as compared to non-CAD. Additionally, levels of HDL-C were significantly lower in CAD as compared to non-CAD patients.

Genotype distribution and allele frequencies of (607C/A) and $(137 G / C)$ polymorphisms in IL-18 promoter gene:

The genotype distribution and allele frequencies of IL-18 promoter gene polymorphisms $(607 \mathrm{C} / \mathrm{A})$ and $(137 \mathrm{G} / \mathrm{C})$ in the different studied groups are shown in (Table 3 ).

For IL-18(607C/A), the frequency of the mutant CA genotype was fundamentally lower in patients with CAD contrasted with non-CAD and

TABLE 1. Anthropometric characteristics of patients with and without CAD.

\begin{tabular}{|c|c|c|c|}
\hline Variables. & Without CAD $(n=60)$ & $\operatorname{CAD}(n=60)$ & P Values \\
\hline Age (years) & $52.1 \pm 10.18$ & $53.3 \pm 8.3$ & 0.136 \\
\hline $\begin{array}{cc}\text { Gender } & \\
& \text { Male (M) } \\
& \text { Female (F) }\end{array}$ & $\begin{array}{l}27(45 \%) \\
33(55 \%)\end{array}$ & $\begin{array}{l}40(66.7 \%) \\
20(33.3 \%)\end{array}$ & 0.013 \\
\hline $\begin{array}{r}\text { Diabetes Mellitus (DM) } \\
\text { Positive (+) } \\
\text { Negative (-) }\end{array}$ & $\begin{array}{l}21(35 \%) \\
39(65 \%)\end{array}$ & $\begin{array}{l}21(35 \%) \\
39(65 \%)\end{array}$ & 0.576 \\
\hline $\begin{array}{l}\text { Positive (+) } \\
\text { Negative (-) }\end{array}$ & $\begin{array}{l}21(35 \%) \\
39(65 \%)\end{array}$ & $\begin{array}{l}22(36.7 \%) \\
38(63.3 \%)\end{array}$ & 0.500 \\
\hline $\begin{aligned} & \text { Hypertension }(\mathrm{HTN}) \\
& \text { Positive (+) } \\
& \text { Negative (-) }\end{aligned}$ & $\begin{array}{l}28(46.7 \%) \\
32(53.3 \%)\end{array}$ & $\begin{array}{l}33(55 \%) \\
27(45 \%)\end{array}$ & 0.233 \\
\hline $\begin{aligned} & \text { Smoking } \\
& \text { Positive (+) } \\
& \text { Negative (-) }\end{aligned}$ & $\begin{array}{l}10(16.7 \%) \\
50(83.3 \%)\end{array}$ & $\begin{array}{l}11(18.3 \%) \\
49(81.7 \%)\end{array}$ & 0.500 \\
\hline LVEDD $(\mathrm{mm})$ & $5.2 \pm 0.534$ & $5.7 \pm 0.512$ & 0.403 \\
\hline $\operatorname{LVESD}(\mathrm{mm})$ & $3.9 \pm 0.622$ & $4.7 \pm 0.585$ & 0.604 \\
\hline LVSWT (mm) & $1.14 \pm 1.04$ & $1.02 \pm 0.1807$ & 0.187 \\
\hline LVPWT(mm) & $1.016 \pm 0.122$ & $1.03 \pm 0.107$ & 0.572 \\
\hline LA & $3.61 \pm 0.561$ & $3.92 \pm 0.496$ & 0.175 \\
\hline $\mathrm{AR}$ & $2.99 \pm 0.434$ & $3.29 \pm 0.254$ & 0.008 \\
\hline RV & $2.46 \pm 0.477$ & $2.35 \pm 0.284$ & 0.000 \\
\hline
\end{tabular}

Data are expressed as mean \pm SD for quantitative variable or number (\%) for qualitative one.

SBP: Systolic blood pressure

LVEDD: Left ventricular end-diastolic diameter

LVESD: Left ventricular end-systolic diameter

LVSWT: Left ventricular systolic wall thickening

LVPWT: Left ventricular posterior wall thickening

LA: Left atrium AR: Aortic root RV: Right ventricle

$\mathrm{EF} \%$ : Ejection fraction $\quad \mathrm{FS} \%$ : Fractional shortening

Bold values indicate a significant difference $\quad \mathrm{P} \leq 0.05$ was considered significant.

Egypt. J. Chem. 60, No. 5 (2017) 
TABLE 2. Lipid Profile levels in the different studied groups.

\begin{tabular}{|l|c|c|c|c|}
\hline \multicolumn{1}{|c|}{ Variables } & $\begin{array}{c}\text { Control } \\
(\mathbf{n = 5 0 )}\end{array}$ & $\begin{array}{c}\text { Non- CAD } \\
(\mathbf{n = 6 0 )}\end{array}$ & $\begin{array}{c}\text { CAD } \\
(\mathbf{n = 6 0})\end{array}$ & P Values \\
\hline Total Cholesterol (mg/ dl) & $172 \pm 24.25$ & $212 \pm 24.16$ & $279 \pm 45.25^{\mathrm{a}}$ & $<0.001$ \\
\hline Triglyceride $(\mathrm{mg} / \mathrm{dl})$ & $115.7 \pm 13.8$ & $155.6 \pm 24.95$ & $186.6 \pm 35.39^{\mathrm{a}}$ & $<0.05$ \\
\hline HDL Cholesterol (mg/ dl) & $80.98 \pm 10.39$ & $63.65 \pm 10.55$ & $48.61 \pm 9.92$ & 0.765 \\
\hline LDL Cholesterol (mg/ dl) & $67.9 \pm 16.3$ & $120.7 \pm 13.49$ & $192.9 \pm 41.31^{\mathrm{a}}$ & $<0.001$ \\
\hline Total C/HDL-C & $2.1 \pm 0.188$ & $3.37 \pm 0.52$ & $5.9 \pm 1.32^{\mathrm{a}}$ & $<0.001$ \\
\hline
\end{tabular}

Data are expressed as mean \pm SD for quantitative variables

Bold values indicate a significant difference $\quad \mathrm{P} \leq 0.05$ was considered significant.

TABLE 3.Genotype distribution and allele frequencies of $(607 \mathrm{C} / \mathrm{A})$ and $(137 \mathrm{G} / \mathrm{C})$ polymorphism in IL-18 gene for patients with and without CAD and control groups.

\begin{tabular}{|c|c|c|c|c|c|c|c|}
\hline \multicolumn{3}{|c|}{ Loci } & \multirow{2}{*}{$\begin{array}{c}\text { CAD } \\
9(15 \%)\end{array}$} & \multirow{2}{*}{$\begin{array}{l}\text { Control } \\
4(8 \%)\end{array}$} & \multirow{2}{*}{$\begin{array}{c}\text { P Value } \\
0.166\end{array}$} & \multirow{2}{*}{$\begin{array}{c}\text { Non-CAD } \\
13(21.7 \%)\end{array}$} & \multirow{2}{*}{$\begin{array}{c}\text { P Values } \\
0.029\end{array}$} \\
\hline & & AA & & & & & \\
\hline \multirow{4}{*}{$\begin{array}{c}\text { IL-18- } \\
607(C>A)\end{array}$} & \multirow[t]{2}{*}{ Genotype } & $\mathrm{CC}$ & $12(20 \%)$ & $4(8 \%)$ & 0.046 & $23(38.3 \%)$ & 0.000 \\
\hline & & $\mathrm{CA}$ & $39(65 \%)$ & $42(84 \%)$ & 0.739 & $24(40 \%)$ & 0.027 \\
\hline & \multirow{2}{*}{ Allele } & A & $57(47.5 \%)$ & $50(50 \%)$ & 0.499 & $50(41.7 \%)$ & 1.000 \\
\hline & & $\mathrm{C}$ & $63(52.5 \%)$ & $50(50 \%)$ & 0.221 & $70(58.3 \%)$ & 0.068 \\
\hline \multirow{5}{*}{$\begin{array}{c}\text { IL-18- } \\
137(\mathrm{G}>\mathrm{C})\end{array}$} & \multirow{3}{*}{ Genotype } & GG & $27(45 \%)$ & $12(24 \%)$ & 0.016 & $25(41.7 \%)$ & 0.033 \\
\hline & & $\mathrm{CC}$ & $6(10 \%)$ & $10(20 \%)$ & 0.317 & $7(11.7 \%)$ & 0.467 \\
\hline & & GC & $27(45 \%)$ & $28(56 \%)$ & 0.893 & $28(46.7 \%)$ & 1.000 \\
\hline & \multirow{2}{*}{ Allele } & $\mathrm{G}$ & $81(67.5 \%)$ & $52(52 \%)$ & 0.012 & $78(65 \%)$ & 0.023 \\
\hline & & $\mathrm{C}$ & $39(32.5 \%)$ & 48 (48\%) & 0.335 & $42(35 \%)$ & 0.527 \\
\hline
\end{tabular}

Data are expressed as number (\%) for qualitative variables.

Bold values indicate a significant difference $\quad \mathrm{P} \leq 0.05$ was considered significant.

control, while, the frequencies of the mutant AA and the wild $\mathrm{CC}$ genotypes were altogether lower in $\mathrm{CAD}$ group when compared to non-CAD and control groups. Additionally, the mutant A allele demonstrated a fundamentally significantly lower frequency in patients with $\mathrm{CAD}$ as compared to non-CAD and control groups, while, the wild $\mathrm{C}$ allele demonstrated a significant lower frequency in patients with $\mathrm{CAD}$ compared to non-CAD and control .

For IL-18 (137G/C), the findings uncovered that the frequency of the mutant GC genotype was altogether lower in CAD when compared to nonCAD and control, while, the wild GG genotype demonstrated higher frequency in CAD group when compared to non-CAD and control. There was no critical distinction among various studied groups in regards to distribution of the mutant CC genotype. On the other side, the frequency of the mutant $\mathrm{C}$ allele demonstrated an essentially lower level in patients with CAD compared to non-CAD and control groups, while the frequency of the wild $\mathrm{G}$ allele demonstrated an altogether higher in CAD group compared to non-CAD and control groups.

\section{Discussion}

Coronary artery disease is a multifactorial

Egypt. J. Chem. 60, No. 5 (2017) 
issue and its pathogenesis is not yet completely understood [17].

A positive relationship of sex in patients with coronary artery disease was observed. This is in concurrence with Hemingway et al [18] and Roger et al [19]. It provides the idea that the pathophysiology of CAD differs amongst women and men and this can be clarified by Dickerson et al [20] who demonstrated that on cardiovascular computed tomography, women have been appeared to have smaller coronary artery diameters than men do likewise, ladies need aid additional doubtful over men would will have obstructive lowlife at the chance about coronary angiography.

We demonstrated that a critical increment in lipid parameters; cholesterol, triglycerides, low density lipoprotein and a critical decline in high density lipoprotein in CAD patients. Likewise, a positive relationship of TC/HDL ratio in $\mathrm{CAD}$ patients was watched. These outcomes are in the same line with the results of Hammoudeh et al [21], Mohsen et al [22] and Yang et al [23].

This might be clarified on the foundation that (LDL) is the essential atherogenic lipoprotein and (HDL) is the predominant hostile to atherosclerotic lipoprotein; where LDL transports cholesterol from the liver to peripheral tissues and advances the foaming of macrophages inside the arterial wall. Alternately, HDL animates the efflux of abundance cell cholesterol and contrarily transports it to the liver.

Yang et al [23] showed that the degree between the atherogenic and defensive lipoproteins, and have more prominent prescient force for evaluating the degree of lipid gathering in the blood vessel mass of atherosclerotic intimal changes.

Rafaela et al [24] demonstrated that expansions in triglycerides lead to expanded danger of coronary events and progression of coronary artery disease, in addition to the formation of new lesions.

Regarding TC/HDL proportion, its association with the presence and seriousness of CAD, clinical and angiographic studies has connected it with the progression or regression of CAD [25]. Subsequently, this finding reinforces the significance of the estimation of the TC/HDL proportion as an individual risk factor for CAD, additionally as an indicator of extent of the disease, even within the sight of cholesterol levels

Egypt. J. Chem. 60, No. 5 (2017) considered typical, hence proposing the imbalance between TC and HDL levels plays more essential part in the pathophysiology of atherogenesis [24].

Our results found that $(607 \mathrm{C} / \mathrm{A})$ IL-18 promoter variant was not connected with $\mathrm{CAD}$, while the wild GG genotype and/or the G allele of the $(137 \mathrm{G} / \mathrm{C}) \mathrm{IL}-18$ indicated a huge relationship in patients with CAD. Our discoveries were supported by Zhang et al [8], Koch et al [9], Mahajan et al [26] and Gurram et al [27] who examined the relationship between (137G) allele with expanded danger of larger artery atherosclerosis.

Likewise, Hernesniemi et al [3] exhibited that (SNP) at position $(137 \mathrm{G} / \mathrm{C})$ was connected with the event of sudden cardiac death among Caucasian males. In support of this discovering, Liu et al [28] proposed that $137 \mathrm{G} / \mathrm{C}$ polymorphism influenced the advancement of atherosclerosis in the Chinese Han populace.

Despite what might be expected, the last study was conflicting with the comparative study described by Fang et al [29] who reported that IL18 (607 C/A) might be connected with danger of acute myocardial infarction in northern Chinese Han populace.

Moreover, Liu et al [28] assessed the relationship between angiographically demonstrated $\mathrm{CAD}^{+}$patients and $\mathrm{CAD}^{-}$people and the promoter locale SNP (G-to-C) of IL-18 at position - 137. A critical increment of $\mathrm{G}$ allele or GG-genotype was seen in $\mathrm{CAD}^{+}$patients contrasted with CAD-individuals, demonstrating that the GG homozygote had a higher event rate for $\mathrm{CAD}^{+}$when contrasted with the $\mathrm{C}$ allele.

On the contrary, Lu et al [30], Opstad et al [31] and Tsai et al [32] have presented that genetic polymorphisms of IL-18 (- 607A/C) and $(-137 \mathrm{C} / \mathrm{G})$ may influence the immune reaction, and can have a part in the risk of a several sorts of diseases. Our findings uncovered that there was no significant difference in IL-18 (607C/A) and $(137 \mathrm{G} / \mathrm{C})$ in CAD patients and also patients without $\mathrm{CAD}$ and controls.

These data agreed by Shayan et al [33] who demonstrated that there was no noteworthy distinction in the $-137 \mathrm{G} / \mathrm{C}$ and $-607 \mathrm{C} / \mathrm{A}$ between both subgroups of patients $\{(\mathrm{CAD}$ with $\mathrm{MI})$ and (CAD without MI) $\}$ and control group.

The study found no relationship between
Egypt. J. Chem. 60, No. $5(2017)$ 
$(607 \mathrm{C} / \mathrm{A})$ and $(137 \mathrm{G} / \mathrm{C})$ polymorphisms and $\mathrm{CAD}$ risk factors (diabetes, hypertension, smoking and obesity) and this is in accordance with those noted by Shayan et al [33] who examined IL18 genotypes with some risk of exposure for CAD and the outcomes did not demonstrate a relationship between them.

This study is one of the first studies exploring the role of IL-18 gene promoter polymorphism in the etiology of CAD and its relation with risk factors in Egyptian populations. Further evidence of the real roles of IL-18 gene polymorphism in the pathogenesis of developing CAD in Egyptian population should be investigated by large population-based studies. Since coronary artery disease remains an important focus of investigation in the order it could be identified and predicted early to help clinicians manage the patients better.

\section{Conclusion}

Inflammation, a major contributor to atherosclerosis and CAD pathogenesis, and investigations of inflammatory biomarkers could be used in diagnosing, prognosticating and managing $\mathrm{CAD}$.

We concluded that the elevation of total cholesterol (TC), triglycerides (TG), low-density lipoprotein-cholesterol (LDL-C) and lowered high-density lipoprotein-cholesterol (HDL-C) are conventional risk factors in coronary artery disease patients.

The major finding of the present study is that G allele and/ or GG genotype at position-137 in IL-18 promoter gene polymorphism could be a risk factor for coronary artery disease and may have protective effects. Whereas, IL-18 (607C/A) gene polymorphism is not associated with the risk of coronary artery disease.

\section{Conflict of Interests}

The authors declare that they have no conflict of interests.

\section{Acknowledgments}

This work was supported by grants from the National Research Centre (NRC) and by Academy of Scientific Research and Technology (ASRT) Fund (For PhD, Code no. R6), Egypt. We thank the patients and volunteers who participate in the study.

\section{References}

1. Ruff, C.T., Braunwald, E. The evolving epidemiology of acute coronary syndromes. Nat Rev Cardiol 8,140-7 (2011).

2. Wilson, J.M. Diagnosis and treatment of acquired coronary artery disease. Postgrad Med J 85 (1005), 364-5(2009).

3. Hernesniemi, J.A., Karhunen, P.J., Rontu, R., Ilveskoski, E., Kajander, O., Goebeler, S., et al. Interleukin-18 promoter polymorphism associates with the occurrence of sudden cardiac death among Caucasian males: the Helsinki Sudden Death Study. Atherosclerosis 196, 643-9 (2008).

4. Baumann, B., Salem, H.H., Boehm, B.O. Antiinflammatory therapy in type 1 diabetes. Curr Diab Rep 12,499-509 (2012).

5. Ghazouani, L., Abboud, N., Khalifa, S., Added, F., Khalfallah AB, Nsiri B, et al. 174G $>$ C interleukin-6 gene polymorphism in Tunisian patients with coronary artery disease. Ann Saudi Med 31(1), 40-4 (2011).

6. Mahajan, K. Interleukin-18 and Atherosclerosis: Mediator or Biomarker. J. Clin. Exp. Cardiolog. 5, 352 (2014).

7. Kim, H.L., Cho, S.O., Kim, S.Y., Kim, S.H., Chung, W.S., Chung, S.H., et al. Association of interleukin-18 gene polymorphism with body mass index in women. Reprod Biol Endocrinol 10, 31 (2012).

8. Zhang, N., Yu, J.T., Yu, N.N., Lu, R.C., Ma, T., Wang, N.D., et al. Interleukin-18 promoter polymorphisms and risk of ischemic stroke. Brain. Res. Bull. 81(6),590-4 (2010).

9. Koch, W., Wolferstetter, H., Schatke, A., Schömig, A., Kastrati, A. Interleukin 18 gene variation and risk of acute myocardial infarction. Cytokine 56(3),786-91 (2011).

10. Yu, X.L., Zhao, F., Zhang, J., Pan, X.M. IL-18 genetic polymorphisms may contribute to the pathogenesis of tuberculosis among Asians: a metaanalysis of case-control studies. Mol. Biol. Rep. 41(9), 6013-23 (2014).

11. Shi, J., Niu, L., Chen, X., Hou, J., Yang, P., Li, G. Investigation on the IL-18 $-607 \mathrm{~A} / \mathrm{C}$ and $-137 \mathrm{C} / \mathrm{G}$ on the susceptibility of ischemic stroke. Pak J. Med. Sci. 31 (1), 198-202 (2015).

12. Allainet, C.C., Poon, L.S., Clau, C.S., Richmond, $\mathrm{W}$. and $\mathrm{Fu}, \mathrm{N}$. Enzymatic determination of total serum cholesterol. Clin Chem 20, 470-75(1974).

13. Fossati, R., Prencipe, L., Serum triglycerides determined colorimetrically with an enzyme 
that produces hydrogen peroxide. Clin Chem 28, 2077-80 (1982).

14. Burstein, M., Scholnick, H.R., Morfin, R., Scand J. Rapid method for the isolation of lipoproteins from human serum by precipitation with polyanions. Clin Lab Invest 40, 560 (1980).

15. Frieldewald, W.T., Levy, R.I., Fredrickson, D.S. Estimation of the concentration of low-density lipoprotein cholesterol in plasma, without use of the preparative ultracentrifuge. Clin.Chem. 18, 499-502 (1972).

16. Giedraitis, V., He, B., Huang, W.X., Hillert, J. Cloning and mutation analysis of the human IL18 promoter: a possible role of polymorphisms in expression regulation. J Neuroimmunol 112(1-2), 146-52 (2001).

17. Moran, A., Gu, D., Zhao, D., Coxson, P., Wang, Y.C., Chen, C.S., et al. Future cardiovascular disease in China: Markov model and risk factor scenario projections from the coronary heart disease policy model - China. Circ Cardiovasc Qual and Outcomes, 3, 243-52 (2010).

18. Hemingway, H., Lanfenberg, C., Damant, J., Frost, C., Pyörälä, K., Barrett-Conor, E. Prevalence of angina in women versus men: a systematic review and meta-analysis of international variations across 31 countries. Circulation, 117,1526-36 (2008).

19. Roger, V.L., Go, A.S., Lloyd-Jones, D.M., Benjamin, E.J., Berry, J.D., Borden, W.B., et al. The American Heart Association Statistics Committee and Stroke Statistics Subcommittee. Heart disease and stroke statistics-2012 update: a report from the American Heart Association. Circulation, 125, e2220 (2012).

20. Dickerson, J.A., Nagaraja, H.N., Raman, S.V. Gender-related, differences in coronary artery dimensions: a volumetric analysis. Clin. Cardiol, 33, 44-9 (2010).

21. Hammoudeh, A., Izraiq, M., Al-Mousa, E., AlTarawneh, H., Elharassis, A., Mahadeen, Z., et al. Serum lipid profiles with and without CAD: Jordan Hyperlipidaemia and Related Targets Study (JoHARTS-1). East Mediterr Health. J. 14(1).

22. Mohsen, M., Ibrahim, A., Shaheen, K., Mona, A. Lipid profile in Egyptian patients with coronary artery disease. The Egyptian Heart J. 65, 79-85 (2013).

23. Yang, C., Zhiqiang, S., Li, Y., Ai1, J. Sun, Q., Tian Y. The correlation between serum lipid profile with carotid intima-media thickness and plaque. $B M C$ Cardiovasc. Disord, 14,181(2014).

24. Rafaela, A., Marçal, H., Luis, C., Gilson, S., Ana-Marice, T. Lipid profile and severity of

Egypt. J. Chem. 60, No. 5 (2017) atherosclerotic disease in acute coronary syndrome. Arq. Bras. Cardiol. 90(1), 24-9(2008).

25. Schwertner, H.Á., Fischer, J.R. Comparison of various lipid, lipoprotein and bilirubin combinations as risk factors for predicting coronary artery disease. Atherosclerosis 150, 381-7 (2000).

26. Mahajan, N., Kapoor, D., Bisht, D., Singh, S., Minz, R.W., Dhawan, V. Levels of interleukin-18 and endothelin-1 in children with Henoch-Schönlein purpura: a study from northern India. Pediatr Dermatol 30, 695-9 (2013).

27. Gurram, V.C., Polipalli, S.K., Karra, V.K., Puppala, M., Pandey, S.K., Kumar, A., et al. Genetic polymorphism of interleukin-18 gene promoter region in rheumatoid arthritispatients from southern India. J. Clin. Diagn. Res. 8(6), SC01-SC04 (2014).

28. Liu, W., Tang, Q., Jiang, H., Ding, X., Liu, Y., Zhu, R., et al. Promoter polymorphism of interleukin-18 in angiographically proven coronary artery disease. Angiology, 60(2), 180-5 (2009).

29. Fang, P., Han, Y., Zhang, X., Yan, C.H., Huang, M., Huang, L., et al. Association of interleukin-18 gene promoter polymorphisms with risk of acute myocardial infarction in northern Chinese Han population. Clin. Chem. Lab. Med. 47, 523-29 (2009).

30. Lu, J.X., Lu, Z.Q., Zhang, S.L., Zhi, J., Chen, Z.P., Wang, W.X. Correlation between interleukin-18 promoter $-607 \mathrm{C} / \mathrm{A}$ polymorphism \& susceptibility to ischemic stroke. Braz J. Med. Biol .Res. 46(6), 502-6 (2013).

31. Opstad, T.B., Pettersen, A., Arnesen, H., Seljeflot, I. The coexistence of the IL-18+183 A/G and MMP$9-1562 \mathrm{C} / \mathrm{T}$ polymorphisms is associated with clinical events in coronary artery disease patients. PLoS. One 8(9), e74498 (2013).

32. Tsai, C.T., Hsin, C.H., Hsieh, Y.H., Tang, C.H., Yang, S.F., Lin CW. Impact of interleukin-18 polymorphisms $-607 \mathrm{~A} / \mathrm{C} \&-137 \mathrm{G} / \mathrm{C}$ on oral cancer occurrence \& clinical progression. PLoS One 8(12), e83572 (2013).

33. Shayan, S., Abdi, A.R., Zibaeenezhad, M.J., Haghshenas, M.R., Erfani, N., Ghaderi, A. Interleukin-18 gene polymorphism in patients with and without atherosclerotic coronary artery disease. Iran. Cardiovasc Rese. J. 3(3), 158-63 (2009).

(Received 8/7/2017; accepted 24/8/2017) 


\section{تعدد الأثكال الجينية في منطقة تثغيل جين الإنترلوكين_^ا في مرض الثريان التاجي}

ابر اهيم حسن برعي'، نهلة سمير حسن'، ألفت جميل شاكـرّ، عصمت عاشورّ، محمد البلدراوي؛، ألفت محمد

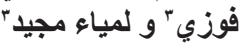

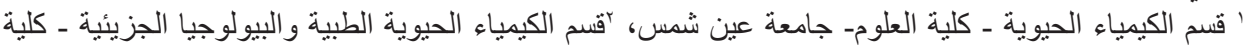

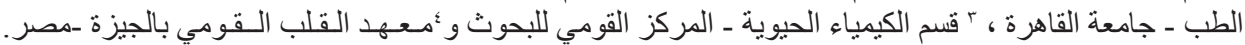

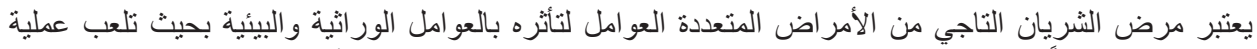

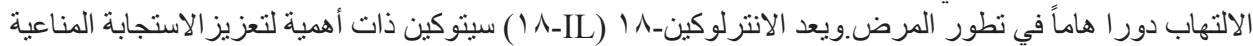

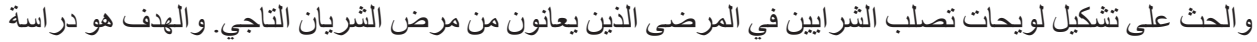

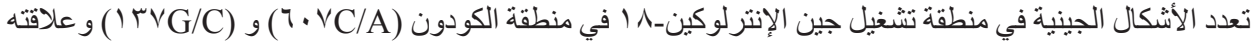

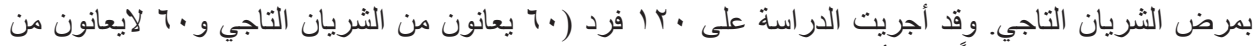

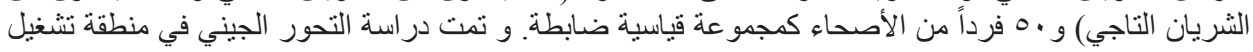

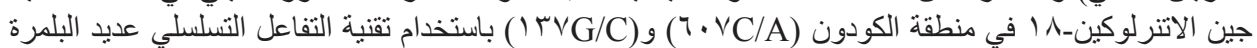

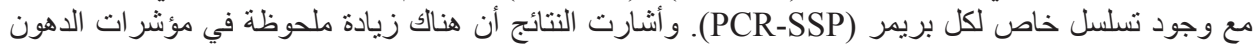

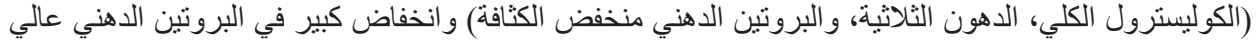

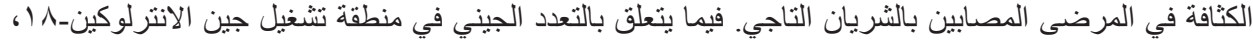

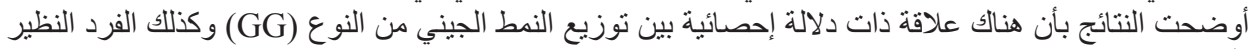

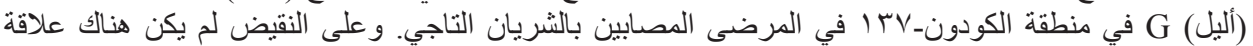

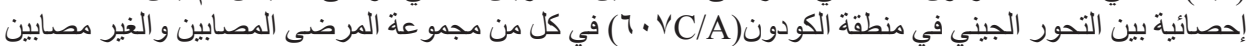

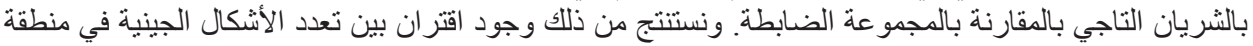

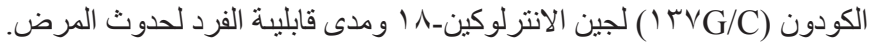

